\title{
The definition of neutrophil extracellular traps and the concentration of short-chain fatty acids in salmonella-induced inflammation of the intestine against the background of vancomycin and Bacteroides fragilis
}

\author{
Yu. V. Bukina ${ }^{1}$, B. O. Varynskyi ${ }^{1}$, A. V. Voitovich ${ }^{1}$, G. D. Koval ${ }^{2}$, A. G. Kaplaushenko $0^{1}$, \\ O. M. Kamyshnyi ${ }^{1}$
}

${ }^{1}$ Zaporizhzhia State Medical University, Ukraine, ${ }^{2} \mathrm{HSEE}$ “Bukovinian State Medical University”, Chernivtsi, Ukraine

\begin{abstract}
Key words:
microbiome,

salmonella,

bacteroides, neutrophil traps,

short chain

fatty acids,

chromatography-

mass spectrometry,

immunofluo-

rescence.

Pathologia

2018; 15 (1), 10-17

DOI:

10.14739/2310-1237.

2018.1.128847

E-mail:

lingvus25@gmail.com

The aim is to study the features of the formation of neutrophil extracellular traps in the blood and gut-associated lymphoid tissue with salmonella-induced inflammation against the background of the administration of vancomycin and B. fragilis, and to determine the concentration of short-chain fatty acids in the luminal microflora of rats by means of chromatography-mass spectrometry.

Methods. Studies were carried out on quantitative counting of Sytox+-neutrophiles and NETs in scrapings of the mucous membrane of the ileum of the intestine and in blood by the method of immunofluorescence microscopy, and also by determination of the concentration of SCFA in the luminal microflora of rats by chromatography-mass spectrometry.

Results. The introduction of vancomycin contributed to an increase in the number of Sytox ${ }^{+}$-cells in scrapings of the intestinal mucosa and in the blood by $55 \%$ and 2.5 times (group II). With the combined administration of vancomycin and $\mathrm{S}$. enteritidis (III group), S. typhimurium (IV group), the mean Sytox+-cell counts in mucosal scrapings increased by $30 \%$ and 2.4 times, and in the blood by $30 \%$ (group IV), there was also a decrease in the number of NETs by $40 \%$ (group IV). The introduction of $\mathrm{B}$. fragilis against the rbackground of pretreatment with vancomycin and infection with salmonella showed a decrease of Sytox+-cells in the scrapings of the intestinal mucosa by $43 \%$ and $53 \%$, and in the blood by $46 \%$ and $58 \%$ (V and VI groups), and the number of NETs in scrapings from the intestinal mucosa and in the blood significantly increased by $43 \%$ and $40 \%$ (V group), and by 2.3 and 2.0 times (group VI). When infecting the rats with $\mathrm{S}$. typhimurium against the background of pretreatment with vancomycin and the introduction of $B$. fragilis, the concentration of acetate in the samples increased by 2 times; propionate -6 times and butyrate -3 times.

Conclusions. The introduction of $\mathrm{B}$. fragilis in the infection of $\mathrm{S}$. enteritidis and $\mathrm{S}$. typhimurium against the background of vancomycin pretreatment leads to decrease in the number of Sytox+-cells in scrapings from the intestinal mucosa and in the blood, but induces the generation of NETs, and also causes an increase in the concentration of SCFA in the luminal microflora of rats, which helps to reduce salmonella-induced inflammation and restore the integrity of the intestinal epithelium.
\end{abstract}

Ключові слова: мікробіом, сальмонела, бактероїди, нейтрофільні пастки, коротколанцюгові жирні кислоти, хромато-масспектрометрія, імунофлуоресценція.

Патологія. - 2018. -

T. 15, № 1(42). -

C. $10-17$
Визначення нейтрофільних позакиітинних пасток і концентрації коротколанцюгових жирних кислот при сальмонела-індукованому запаленні кишечника на тлі введення ванкоміцину та Bacteroides fragilis

\section{Ю. В. Букіна, Б. О. Варинський, О. В. Войтович, Г. А. Коваль, А. Г. Каплаушенко, О. М. Камишний}

Мета роботи - вивчити особливості формування нейтрофільних позаклітинних пасток у крові та кишково-асоційованій лімфоїдній тканині при сальмонела-індукованому запаленні на тлі введення ванкоміцину і B. fragilis, a також визначити концентрацію коротколанцюгових жирних кислот у просвітній мікрофлорі щурів за допомогою хромато-мас-спектрометрії.

Матеріали та методи. Здійснили дослідження за кількісним підрахунком Sytox+-нейтрофілів і НПП у зіскрібках слизової оболонки клубового відділу кишечника та у крові методом імунофрлуоресцентної мікроскопії, а також визначення концентрації КЛЖК у просвітній мікрофрорі щурів хромато-мас-спектрометричним методом.

Результати. Введення ванкоміцину сприяло збільшенню кількості Sytox+-клітин у зіскрібках слизової оболонки кишечника та у крові на 55 \% і в 2,5 раза (II група). При одночасному введенні ванкоміцину та S. enteritidis (III група), S. typhimurium (IV група) середнє значення Sytox+-клітин у зіскрібках зі слизової оболонки збільшилося на 30 \% і в 2,4 раза, а в крові на 30 \% (IV група), також визначили зменшення кількості НПП на 40 \% (IV група). Введення B. fragilis на тлі попередньої обробки ванкоміцином та інфікування сальмонелами показало зниження Sytox+-клітин у зіскрібках слизової оболонки кишечника на 43 \% та 53 \%, у крові - на 46 \% і 58 \% (V i VI групи), а кількість НПП у зіскрібках зі слизової оболонки кишечника та у крові збільшувалася на 43 \% і 40 \% (V група), а також у 2,3 i 2,0 раза (VI група). При інфікуванні щурів S. typhimurium на тлі попередньої обробки ванкоміцином і введення B. fragilis концентрація ацетату у зразках збільшилася вдвічі, пропіонату - у 6 разів, бутирату - у 3 рази.

Висновки. Введення B. fragilis при інфрікуванні S. enteritidis i S. typhimurium на тлі попередньої обробки ванкоміцином призводить до зменшення кількості Sytox ${ }^{+}$-клітин у зіскрібках слизової оболонки клубової кишки та у крові, але індукує генерацію НПП, а також зумовлює збільшення концентрації КЛЖК у просвітній мікрофлорі щурів, що сприяє зменшенню сальмонела-індукованого запалення, відновленню цілісності епітелію кишечника. 


\section{Определение нейтрофильных внеклеточных мовушек и концентрации короткоцепочечных жирных кислот при сальмонема-индуцированном воспалении кишечника на фоне введения ванкомицина и Bacteroides fragilis}

\section{Ю. В. Букина, Б. А. Варинский, А.В. Войтович, Г. А. Коваль, А. Г. Каплаушенко, А. М. Камышный}

Цель работы - изучить особенности формирования нейтрофильных внеклеточных ловушек в крови и кишечно-ассоциированной лимфоидной ткани при сальмонелла-индуцированном воспалении на фоне введения ванкомицина и B. fragilis, а также определить концентрацию короткоцепочечных жирных кислот в просветной микрофлоре крыс при помощи хромато-масс-спектрометрии.

Материалы и методы. Проведены исследования по количественному подсчету Sytox+-нейтрофилов и НВЛ в соскобах слизистой оболочки подвздошного отдела кишечника и в крови методом иммунофолуоресцентной микроскопии, а также по определению концентрации КЦЖК в просветной микрофлоре крыс хромато-масс-спектрометрическим методом.

Результаты. Введение ванкомицина способствовало увеличению числа Sytox+-клеток в соскобах слизистой оболочки кишечника и в крови на 55 \% и в 2,5 раза (II группа). При сочетанном введении ванкомицина и S. enteritidis (III группа), S. typhimurium (IV группа) среднее значение Sytox+-клеток в соскобах со слизистой оболочки увеличилось на 30 \% и в 2,4 раза, а в крови на 30 \% (IV группа), также отмечено снижение численности НВЛ на 40 \% (IV группа). Введение B. fragilis на фоне предобработки ванкомицином и инфицировании сальмонеллами показало снижение Sytox+-клеток в соскобах слизистой оболочки кишечника на 43 \% и 53 \%, в крови - на 46 \% и 58 \% (V и VI группы), а количество НВЛ в соскобах со слизистой оболочки кишечника и в крови увеличивалась на 43 \% и 40 \% (V группа), а также в 2,3 и 2,0 раза (VI группа). При инфицировании крыс S. typhimurium на фоне предобработки ванкомицином и введении B. fragilis концентрация ацетата в образцах увеличилась в 2 раза, пропионата - в 6 раз, бутирата - в 3 раза.

Выводы. Введение B. fragilis при инфицировании S. enteritidis и S. typhimurium на фоне предобработки ванкомицином приводит к снижению численности Sytox+-клеток в соскобах слизистой оболочки подвздошной кишки и в крови, но индуцирует генерацию НВЛ, а также обусловливает увеличение концентрации КЦЖК в просветной микрофлоре крыс, что способствует снижению сальмонелла-индуцированного воспаления и восстановлению целостности эпителия кишечника.

Intestinal microbiome is a unique system responsible for maintaining the body's homeostasis. This constancy is ensured by the interaction of representatives of microflora with gut-associated lymphoid tissue (GALT) through a certain group of molecules - short-chain fatty acids (SCFA) [1]. These acids are metabolic products of anaerobic bacteria that are capable of influencing chemotaxis, apoptosis, T-cell differentiation, the transcriptional activity of the FFAR2, Foxp3 and RORyt genes and activation of the receptors for acetate, propionate and butyrate (GPR43, GPR41 and GPR109a (HCA2)). One of the main producers of SCFA in GALT are bacteroides [2-4]. We showed previously that the administration of B.fragilis against the background of vancomycin pretreatment and salmonella infection increases the mRNA level of the FFAR2 gene, and also increases the transcriptional activity of the Foxp3 gene directing T-cell differentiation toward Treg, which contributed to a decrease in inflammatory reactions in the intestine and recovery of the microbiome development of experimental gastroenteritis [5].

Meanwhile, the effect of changes in the level of SCFA on the functional activity of some of the main cells of innate immunity - neutrophils, practically nothing is known. A recent discovery related to the ability of neutrophils to distinguish lipopolysaccharides from different bacterial agents and selectively release extracellular traps (NETs) is of great interest in studying the mechanisms of interaction of pathogenic microorganisms with immune system cells and their ability to influence the formation of NETs the concentration of SCFA, as a factor affecting the inhibition of inflammatory reactions in the intestine $[6,7]$.

One of the main elements of NETs is DNA $[8,9]$. However, in addition to DNA, NETs include $70 \%$ of histone proteins ( $\mathrm{H} 1, \mathrm{H} 2 \mathrm{~A}, \mathrm{H} 2 \mathrm{~B}, \mathrm{H} 3$ and $\mathrm{H} 4)$, as well as non-his- tone proteins, most notably neutrophil elastase (NE) of $5 \%[10,11]$. Another, not less important part of NETs, is myeloperoxidase (MPO), which has strong antipathogenic properties [12]. The structure of NETs is heterogeneous and can contain a large number of components: cathepsins, defensins, bactericides, phosphatases, lactoferrin, lysozyme, catelicidins, collagenase, gelatinase, catalase. Thanks to active research into the structure of NETs, the scientists showed that the components of NETs also include: cytokeratin-10, $\alpha$-actinin 1 and $4, \beta$-actin, $\gamma$-actin, myosin-9, cytoplasmic proteins, proteinase 3 , catellicidins (LL-37), tryptases, glycolytic enzymes, a-enolase and transketolase [13-15].

Salmonella are one of the inducers of the formation of NETs. Interestingly, there is the fact that taking antibiotics can also stimulate the formation of NETs, which leads to inhibition of the growth of pathogenic microorganisms [16]. Therefore, the study of the nature of generation of NETs with the administration of S. typhimurium, S. enteritidis, vancomycin and Bacteroides fragilis is of particular interest.

\section{The aim}

To study the features of the formation of NETs in the blood and GALT with salmonella-induced inflammation against the background of the administration of vancomycin and B. fragilis, and to determine the concentration of SCFA in the luminal microflora of rats by means of chromatography-mass spectrometry.

\section{Materials and methods of research}

The experiments were carried out on 60 male Wistar rats of 3 months age who were divided into 6 groups (10 each): I-
Киючевые слова: микробиом, сальмонемла, бактероиды, нейтрофильные ^овушки, короткоцепочечные жирные кислоты, хромато-массспектрометрия, иммунофАюоресценция.

Патология. - 2018. T. 15, № 1(42). C. 10-17 
Control (intact rodents) II - Vancomycin (animals that received oral administration of vancomycin at a dose of $50 \mathrm{mg} / \mathrm{kg}$ ); III - Vancomycin + S. enteritidis (animals that received vancomycin at oral dose of $50 \mathrm{mg} / \mathrm{kg}$ and received bacterial load of $S$. enteritidis in an amount of $3 \times 10^{8} \mathrm{CFU} / \mathrm{ml}$ every other day); IV - Vancomycin + S. typhimurium (animals that received vancomycin at the dose of $50 \mathrm{mg} / \mathrm{kg}$ per day and received a bacterial load of S. typhimurium in the amount of $3 \times 10^{8} \mathrm{CFU} / \mathrm{ml}$ every other day); $\mathrm{V}-$ Vancomycin $+\mathrm{S}$. enteritidis $+\mathrm{B}$. fragilis (animals received by oral administration of vancomycin at a dose of $50 \mathrm{mg} / \mathrm{kg}$, a day later - a bacterial load of $\mathrm{S}$. enteritidis in the amount of $3 \times 10^{8} \mathrm{CFU} / \mathrm{ml}$ and the next day of $\mathrm{B}$. fragilis $\left.3 \times 10^{8} \mathrm{CFU} / \mathrm{ml}\right) ; \mathrm{VI}-\mathrm{Vancomycin}+\mathrm{S}$. typhimurium $+B$. fragilis (animals that received vancomycin at oral dose $50 \mathrm{mg} / \mathrm{kg}$, a day later - a bacterial load of S. typhimurium in the amount of $3 \times 10^{8} \mathrm{CFU} / \mathrm{ml}$ and the next day $-B$. fragilis in $3 \times 10^{8} \mathrm{CFU} / \mathrm{ml}$ ). On the fifth day the rats were removed from the experiment in accordance with the principles of euthanasia. Infection of animals was carried out by daily cultures of salmonella grown on $1.5 \%$ of MPA, obtained from the Museum of strains of microorganisms of the Ukrainian Center for Disease Control and Monitoring of the Ministry of Health of Ukraine. Bacteroid cultures were grown on nutrient media prepared according to methodological recommendations "Laboratory diagnostics of purulent inflammatory diseases caused by asporogenous anaerobic microorganisms" (Kharkiv, 2000). Bacterial suspensions were standardized using a DEN-1B (Biosan) densitometer by McFarland (McF). To introduce the $\mathrm{S}$. enteritidis, $\mathrm{S}$. typhimurium and $\mathrm{B}$. fragilis to rats, we prepared suspensions in the concentration of 1.0 McF standards, which corresponds to the concentration of $3 \times 10^{8} \mathrm{CFU} / \mathrm{ml}$.

The evaluation of macroscopic manifestations of ileum deficiency was performed on a scale from 0 to 8 in accordance with the criteria of Morris et al. in the modification of Jagtap [17]: (0) no visible changes, (1) there are areas of hyperemia, (2) there are lesions having a diameter of $1 \mathrm{~mm}$ or less, (3) lesions having a diameter of $2 \mathrm{~mm}$ or less (number $<5$ ), (4) there is a defect having a diameter of $2 \mathrm{~mm}$ or less (number 5-10), (5) a defect having a diameter of $2 \mathrm{~mm}$ or less (>10), (6) there is a lesion, having a diameter of more than $2 \mathrm{~mm}$ (number $<5),(7)$ there are lesions having a diameter greater than $2 \mathrm{~mm}$ (number 5-10); (8) lesions having a diameter greater than $2 \mathrm{~mm}(>10)$.

As a material for conducting the chromatography-mass-spectrometric study to determine the concentration of SCFA (acetate, propionate and butyrate), a luminal microflora of rats was used and only in comparison groups IV and VI.

Sample preparation process: fecal samples $(2 \mathrm{~g})$ were taken into sterile tubes, $1 \mathrm{ml}$ of bidistilled water was added to each by the glass pipette, it was mixed well. Then $1 \mathrm{ml}$ of $0.1 \mathrm{~N}$ hydrochloric acid and $2 \mathrm{ml}$ of diethyl ether were added. The stirring was continued for 25 minutes and it was left for 10 minutes for complete phase separation. Using medical sterile syringes for $1000 \mu \mathrm{l}$, the upper phase was taken, transferred to numbered centrifuge microtubes [18]. To determine the concentration of SCFA, we developed a new methodology for performing of chromatography-mass spectrometric analysis (CMSA). The analysis was carried out using liquid chromatography-mass spectrometer (LC MS): Agilent 1260 Infinity HPLC System (USA) (degasser, binary pump, autosampler, column thermostat); one-wave Agilent 6120 mass spectrometer with electrospray ionization (ESI); OpenLAB CDS Software. In the CMSA study, the following tests were used: 1) Binary gradient-A: $\mathrm{H}_{2} \mathrm{O}$ ( $\mathrm{HCOOH} 0.1 \%), \mathrm{B}: \mathrm{CH}_{3} \mathrm{CN}(\mathrm{HCOOH} 0.1 \%) ; 2$ ) Conditions of gradient $\mathrm{B}$ mode (0 min - 2\%, 10 min - $100 \%$ ); 3) Flow rate $0.4 \mathrm{ml} \mathrm{min}$; 4) Column Zorbax SB-C18; 30.0 $\mathrm{mm} \times 4.6 \mathrm{~mm} ; 1.8 \mu \mathrm{m} ; 5$ ) Column temperature: $40^{\circ} \mathrm{C} ; 6$ ) Ion source: API-ES; 7) Selective ion monitoring mode SIM 61.0; 75.0; 89.0; 8) Fragmentor: 100V; 9) Positive polarity; 10) The nitrogen temperature is $110^{\circ} \mathrm{C}$; 11) Pressure on the nebulizer $60 \mathrm{psi}$; 12) Gas velocity of the desiccant (nitrogen) $-10 \mathrm{l} / \mathrm{min}$; 13) The injection volume is $5 \mu \mathrm{l}$. All data were recorded on chromatograms.

Determination of the average number of Sytox ${ }^{+}$and NETs cells in scrapes taken from the mucous membrane of the ileum of the intestine and in the blood (groups I-VI) was carried out with the immunofluorescence microscope PrimoStar (ZEISS, Germany) in the ultraviolet excitation spectrum of $390 \mathrm{~nm}$ (FITC). Digital image analysis was performed using the AxioVision 4.7.2 system (Imaging Associates Ltd, Germany). The material was taken with a sterile plastic curette from the mucous membrane of the ileum of the intestine and transferred to a sterile slide glass. The drug was fixed with $95 \%$ ethanol for 5 minutes. The excess of ethanol after fixation was removed with the help of filter paper, not allowing the preparation to dry in air. To identify the NETs, the fluorescent dye SYTOX ${ }^{\mathrm{TM}}$ Green nucleic acid stain (Invitrogen, USA) was used, according to the instructions attached to the kit. The drug was additionally stained for 30 seconds by Romanovsky-Giemsa and light and fluorescent microscopy was performed on a $\times 10$ lens in the field of view. In the automatic mode, areas with statistically significant fluorescence characteristic of these cells were determined. Immune-positive cells were studied using the computer program Image $(\mathrm{NIH}$, USA). The morphometric and densitometric characteristics of immune-positive cells were counted. Cells with a circularity $\leq 0.5\left(4 \pi \times[\right.$ Area $\left.] /[\text { Perimeter }]^{2}\right)$ were referred to neutrophils forming NETs.

The statistical analysis of the results was carried out using Microsoft Excel 2016 and StatSoft Statistica v12 (NAXXR712D833214FAN5). To calculate the reliability of the differences between the mean values of the concentration of short chain fatty acids the non-parametric Mann-Whitney criterion (U-test) and the Student's t-criterion for calculating the average number of Sytox ${ }^{+}$and NETs cells were used. Statistically significant differences were considered at a value of $\mathrm{P}<0.05$.

\section{Results and its discussion}

The results obtained in the course of the studies on the quantitative determination of Sytox ${ }^{+}$- cells and NETs in scrapings from the mucous membrane of the ileum of the intestine and in the blood showed that when vancomycin (group II) was administered to experimental animals, an increase in the number of Sytox cells by $55 \%$ and by 2.5 times $(P<0.05)$ compared with the control group. 

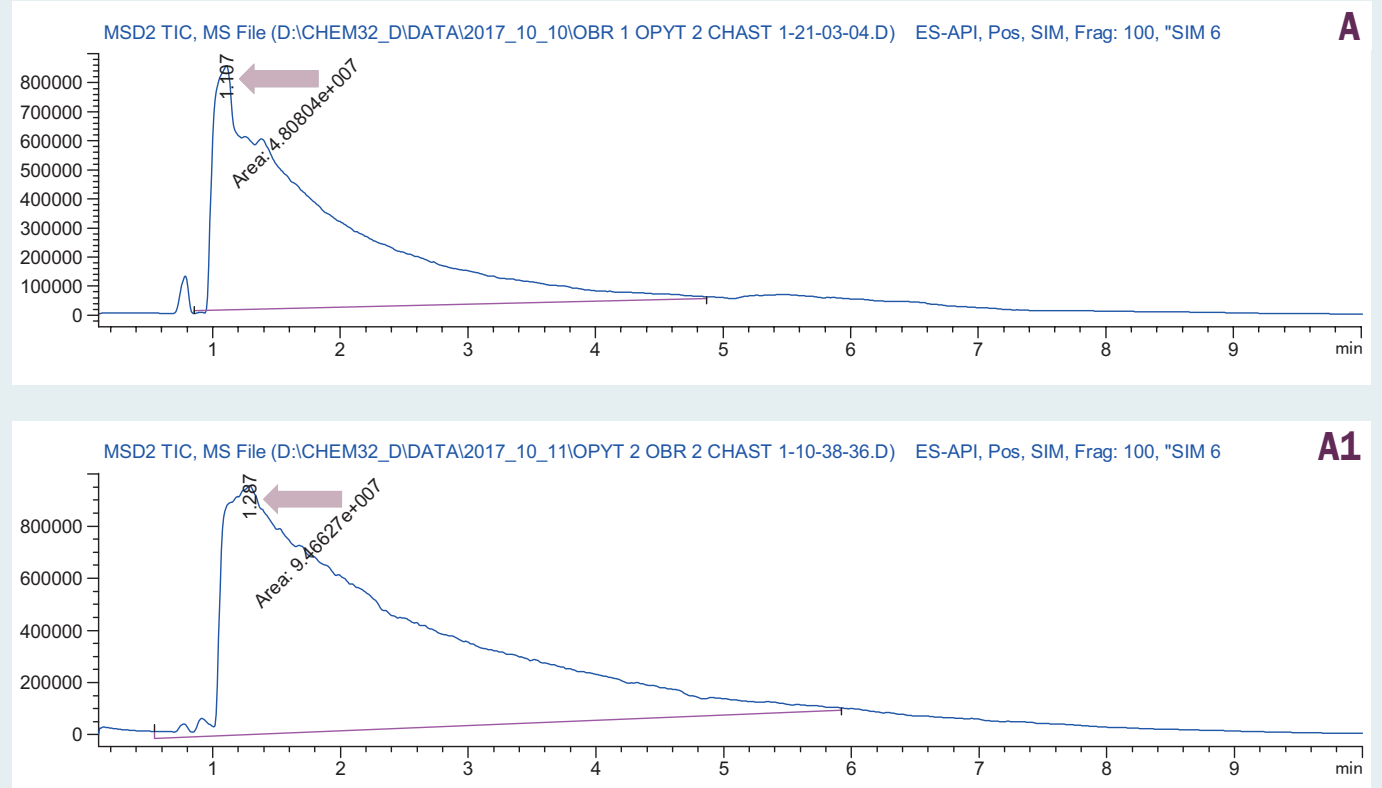

Fig. 1. Chromatograms of acetoacetic acid in the fecal samples.

$\mathbf{A}$ - the content of acetate in animals in the group S. typhimurium + Vancomycin. A1 - the content of acetate in animals in the group S. typhimurium + Vancomycin + B. fragilis.
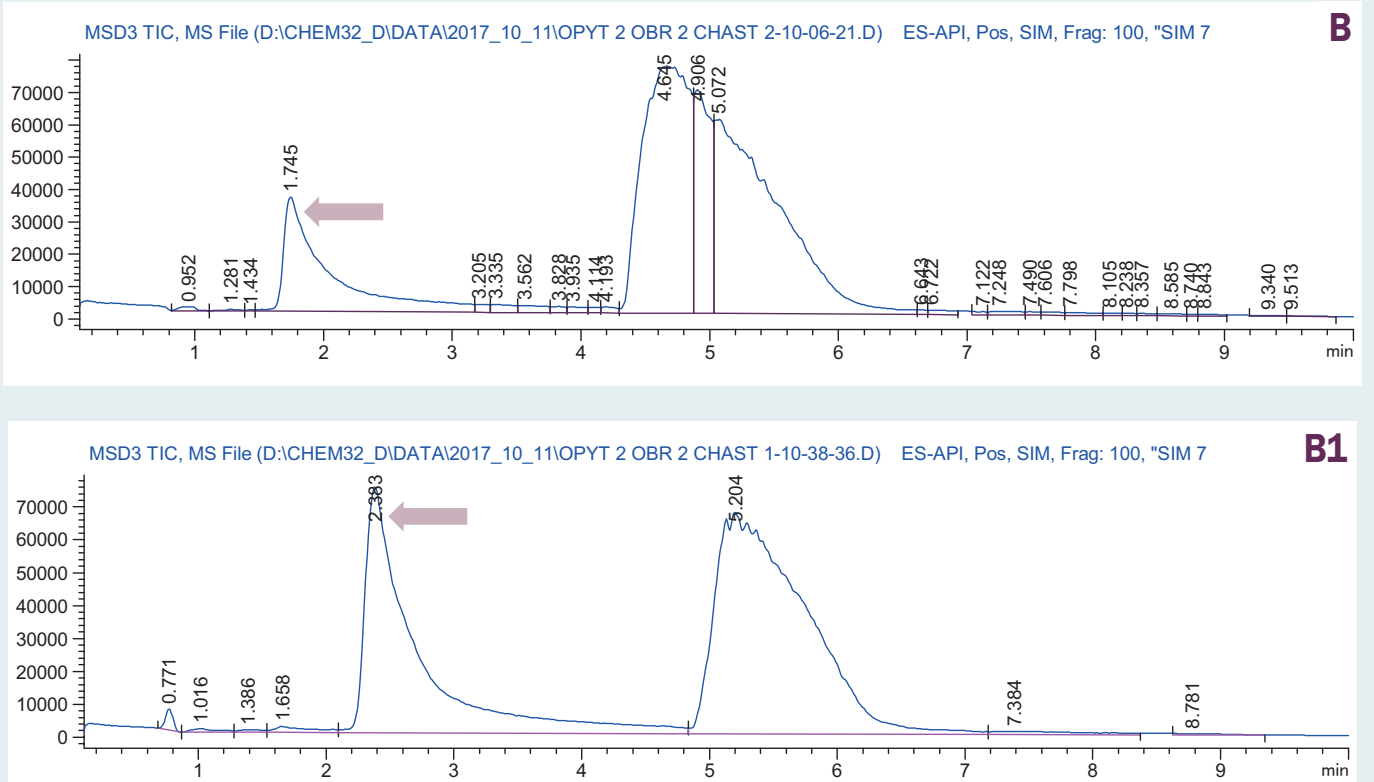

Fig. 2. Chromatograms of propionic acid in the fecal samples.

B - the content of propionate in animals in the group S. typhimurium + Vancomycin. B1 - the content of propionate in animals in the group S. typhim urium + Vancomycin + B. fragilis.

When analyzing the data of groups III and IV, which underwent pretreatment with vancomycin, and after infection with S.enteritidis and S. typhimurium, the average value of Sytox ${ }^{+}$-cells in scrapings from the ileal mucosa increased significantly by $30 \%$ and by 2.4 times, and in the blood by $30 \%$ and only in the IV group $(P<0.05)$, than with the single administration of vancomycin (II group). Also, in scrapings from the ileal mucosa, there was a decrease in the number of NETs by $40 \%$ (group IV) $(\mathrm{P}<0.05)$ (Table 1). Calculation of the average number of Sytox ${ }^{+}$-cells in scrapings from the intestinal mucosa in the $\mathrm{V}$ and $\mathrm{VI}$ groups, where the animals received bacterial strain of $B$. fragilis against the background of vancomycin pretreatment and the introduction of S. enteritidis, S. typhimurium, 
MSD4 TIC, MS File (D:ICHEM32_DIDATAI2017_10_111OBR 3 OPYT 2 CHAST 2-08-32-38.D) ES-API, Pos, SIM, Frag: 100, "SIM 8

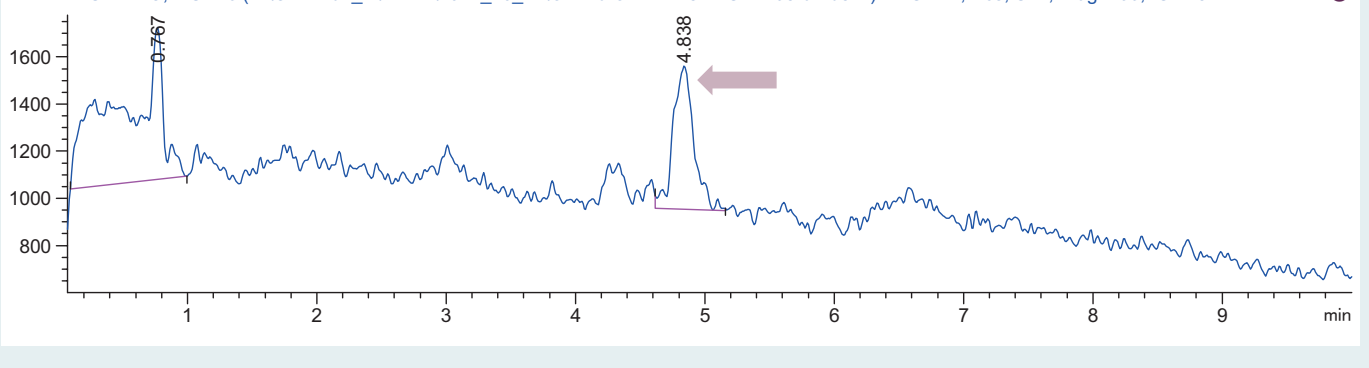

MSD4 TIC, MS File (D:ICHEM32_DIDATAI2017_10_11|OPYT 2 OBR 2 CHAST 1-10-38-36.D) ES-API, Pos, SIM, Frag: 100, "SIM 8

C1

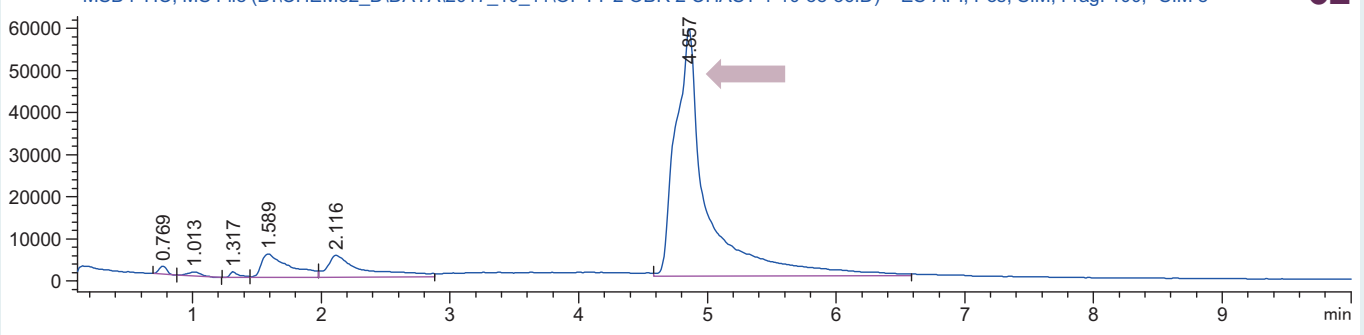

Fig. 3. Chromatograms of butanoic acid in the fecal samples.

C - the content of butyrate in animals in the group S. typhimurium + Vancomycin. $\mathbf{C 1}$ - the content of butyrate in animals in the group S. typhimuriu $m+$ Vancomycin $+B$. fragilis.

decreased by $43 \%$ and $53 \%$, and in the blood - by $46 \%$ and $58 \%(\mathrm{P}<0.05)$ in relation to the results obtained in the analysis of groups III and IV. However, the number of NETs in scrapings from the ileal mucosa and in the blood increased significantly in the $\mathrm{V}$ group by $43 \%$ and $40 \%$, and in the $\mathrm{VI}$ group by 2.3 and 2.0 times, respectively $(P<0.05)$ than in III and IV groups (Table 2$)$.

In the course of the studies, we determined the concentrations of SCFA (acetyl, propionate and butyrate) in the luminal microflora of rats when they were infected with S. typhimurium against the background of the preliminary administration of vancomycin, as well as in combination with $B$. fragilis. Thus, in the infection of rats $S$. typhimurium against the background of pretreatment with vancomycin and in the combined administration of $B$. fragilis, the average concentration of acetate in the samples increased significantly - 2-fold (Fig. 1); propionate - 6 times (Fig. 2) and butyrate -3 times, respectively $(P<0.05)$ (Fig. 3), rather than infecting S.typhimurium animals against the background of the preliminary administration of vancomycin (Table 3).

The formation of NETs (netosis) can take place in three versions: a) cell lysis-suicidal netosis; b) vesicular secretion of nuclear DNA without destruction of MTC neutrophils - vital netosis; c) formation of NETs from mitochondrial DNA $[19,20]$. At present, the most studied model is suicidal netosis, which lasts for $2-4$ hours. Its onset is characterized by neutrophil activation, through the recognition of pathogens, which leads to the induction of the NADPH oxidase (NOX) complex, through protein kinase $\mathrm{C}$, and to an increase in cytosolic $\mathrm{Ca}^{+}$[21-23]. These cations serve as a co-factor for peptidyl-arginase deaminase 4 (PAD4) and a nuclear enzyme that deaminates histones, modifies amino acids, which leads to decondensation of chromatin and loss of positive charges necessary for the interaction of histones with DNA $[24,25]$. Active forms of oxygen contribute to the destruction of the nuclear membrane into small granules and to the mixing of chromatin with cytoplasmic proteins and granular toxins. The formation of NETs depends on the transport of elastase and myeloperoxidase from the granules to the nucleus. This results in the release of chromatin and lysis of the cell with the release of DNA as extracellular traps (NETs) [26,27]. The second type of ECT generation (5-60 min), proceeding without loss of the nuclear or plasma membrane and independent of ROS, is vital netosis. This process is carried out due to three morphological modifications: the growth of the nuclear envelope and the release of vesicles; decondensation of the nucleus; destruction of the nuclear membrane and release of DNA [28-30]. This variant of NETosis is mediated by the effect on Toll-like receptors (TLRs) and complement receptors of the C3 protein [31-33]. In addition, the formation of NETs by neutrophils can be facilitated by the interaction of the glycoprotein $\mathrm{Ib}$ in platelets with $\beta 2$-integrin (CD18), by activating ERK, PI3K and src-kinases [34]. Thus, non-nuclear neutrophils retain the ability to phagocytosis pathogenic microorganisms, regardless of the loss of DNA. The third, ROS-dependent mechanism of NETosis, is the release of mitochondrial DNA, instead of nuclear, by recognizing the lipopolysaccharide (LPS) of bacteria or C5a, resulting in the formation of NETs for 15 min [35-38].

Our results showed that the introduction of bacteroides changes significantly the concentration of SCFA in the intestine and this is accompanied by an increase in the formation of NETs. This is confirmed by other studies on the effect of SCFA on effector functions of neutrophils [39]. SCFA, when interacting with neutrophils, can affect the production of pro-inflammatory cytokines (TNF- $\alpha$ and IL-17) and neutrophil chemoattractants (CXCL1 and 
CXCL8) by initiating the FFAR2 receptor, which results in the induction of neutrophil chemotaxis [40-42]. The inhibitory effect of neutrophils on the production of TNF- $\alpha$ has been described by Tedelind (2007) who showed that this process was mediated by the Toll-like receptor (TLR) agonists and SCFA. When human neutrophils were incubated with TLR2 agonists and SCFA, the production of CXCL8 was noted, which proves the direct effect of free fatty acids on neutrophil activity [43]. The experiments carried out to study the neutrophil functions have shown that under the influence of SCFA, they are capable of releasing reactive oxygen species and nitrogen oxide, which can affect their life cycle. In his works Sina (2009) demonstrated changes in migration of mouse neutrophils under the influence of propionate [44]. At the same time, Le Poul (2003) suggests that intensive neutrophil migration may be due to the presence of formyl-methionyl-leucyl-phenylalanine (fMLP) [45]. In the studies on different experimental models (dextran sulfate-sodium colitis [46], T-cell-dependent colitis [47,48], thioglycollate-induced peritonitis [49], acute renal failure [50]), the researchers determined that activation of SCFA reduces the restructuring of the neutrophil cytoskeleton and the intensity of inflammatory responses. This fact is confirmed by the investigation of Mishiro (2013) that was conducted on mouse models with dextran sulfate-sodium colitis and rectal administration of butyrate in which the weakening of the rearrangement of the cytoskeleton of neutrophils and reduction in inflammation were also observed [51]. The results obtained by Kim (2013), likewise show a reduction in inflammatory responses due to the interaction of neutrophils with SCFA and epithelial cells of the intestine (GPR41), when C. rodentium mice are infected with the subsequent introduction of acetate. However, the results obtained by other scientists showed that SCFAs not only did not influence but sometimes even inhibited phagocytosis and the formation of reactive oxygen species by neutrophils [52,53]. Also, another group of scientists found that with the activation of caspase, propionate and butyrate are capable to launch a neutrophil apoptosis, which is independent of protein kinases and activation of SCFA receptors [54]. Similar studies on SCFA, conducted by Maslovsky (2009), demonstrated the effect of acetate on the induction of neutrophil apoptosis, but, unlike the Aoyama (2010) studies, they indicated the direct involvement of the FFAR2 receptor in this process $[55,56]$. Some of the findings indicate the involvement of SCFA in the infectious process. Thus, scientists, who used a subcutaneous model of opportunistic infection, caused by pathogenic microorganisms A. actinomycetemcomitans, demonstrated that the presence of SCFA did not affect the number of leukocytes, but they reduced significantly the production of cytokines, phagocytic activity and caused the death of bacteria, but did not lead to a change in effector mechanisms of neutrophils. A similar effect that was not associated with the activation of FFAR2 and the main SCFA receptor expressed on the surface of neutrophils was also observed in the stimulation of neutrophils by bacteria, which may have been due to the inhibition of histonedeacetylases [57-59]. Of particular interest are the results of studies obtained by Brinkmann (2004), who showed that the infection of S. typhimurium
Table 1. Average number of Sytox+-neutrophiles and NETs in scrapings from the intestinal mucosa and in the rat blood (Total Density (mean) + S.E.M.) in the field of view

\begin{tabular}{ll|l|l|l|l|} 
Cells & Control & Vancomycin & $\begin{array}{l}\text { S. enteritidis } \\
+ \text { Vancomycin }\end{array}$ & $\begin{array}{l}\text { S. typhimurium } \\
+ \text { Vancomycin }\end{array}$ \\
\hline Sytox & intestines & $17.2 \pm 1.9$ & $26.7 \pm 2.5^{\mathrm{a}}$ & $34.6 \pm 1.9^{\mathrm{b}}$ & $63.0 \pm 3.7^{\mathrm{b}}$ \\
NETs intestines & $8.7 \pm 0.8$ & $8.1 \pm 0.8$ & $7.0 \pm 1.0$ & $4.9 \pm 0.4^{\mathrm{b}}$ \\
\hline Sytox & blood & $12.2 \pm 1.0$ & $30.0 \pm 1.6^{\mathrm{a}}$ & $25.6 \pm 3.7$ & $39.0 \pm 2.9^{\mathrm{b}}$ \\
NETs blood & $7.6 \pm 0.7$ & $5.0 \pm 2.4$ & $6.2 \pm 0.5$ & $5.0 \pm 0.8$ \\
\hline
\end{tabular}

a: reliability of differences in the parameters of $P<0.05$ relative to the control group; ${ }^{b}$ : reliability of differences in the parameters of $P<0.05$ in relation to the Vancomycin group.

Table 2. Determination of the average number of Sytox+ neutrophiles and NETs cells in rats upon administration of $\mathrm{S}$. enteritidis, $\mathrm{S}$. typhimurium and $\mathrm{B}$. fragilis against the background of vancomycin pretreatment (Total Density (mean) + S.E.M.) in the field of view

\begin{tabular}{ll|l|l|l|l} 
Cells & & $\begin{array}{l}\text { S. enteritidis } \\
\text { + Vancomycin }\end{array}$ & $\begin{array}{l}\text { S. typhimurium } \\
\text { + Vancomycin }\end{array}$ & $\begin{array}{l}\text { S. enteritidis + } \\
\text { Vancomycin + } \\
\text { B. fragilis }\end{array}$ & $\begin{array}{l}\text { S. typhimurium } \\
\text { + Vancomycin } \\
\text { + B. fragilis }\end{array}$ \\
\hline Sytox ${ }^{+}$ & intestines & $34.6 \pm 1,9$ & $63.0 \pm 3.7$ & $19.7 \pm 1.6^{*}$ & $29.7 \pm 2.8^{*}$ \\
\hline NETs & intestines & $7.0 \pm 1.0$ & $4.9 \pm 0.4$ & $10.0 \pm 1.0^{*}$ & $11.4 \pm 1.9^{*}$ \\
\hline Sytox ${ }^{+} \quad$ blood & $25.6 \pm 3.7$ & $39.0 \pm 2.9$ & $13.8 \pm 1.9^{*}$ & $16.3 \pm 1.9^{*}$ \\
\hline NETs & blood & $6.2 \pm 0.5$ & $5.0 \pm 0.8$ & $8.7 \pm 0.9^{*}$ & $9.8 \pm 1.2^{*}$ \\
\hline
\end{tabular}

*: the reliability of differences in the parameters of $p<0.05$ in relation to the groups $\mathrm{S}$. enteritidis + Vancomycin and S. typhimurium + Vancomycin.

Table 3. Determination of the average content of SCFA in the luminal microflora of rats, $\mathrm{g} / \mathrm{ml}$

\begin{tabular}{l|l|l} 
SCFA & $\begin{array}{l}\text { S. typhimurium } \\
+ \text { Vancomycin }\end{array}$ & $\begin{array}{l}\text { S. typhimurium } \\
+ \text { Vancomycin + B. fragilis }\end{array}$ \\
\hline Acetate & $1.1 \times 10^{-3}$ & $2.3 \times 10^{-3^{*}}$ \\
\hline Propionate & $4.0 \times 10^{-6}$ & $2.3 \times 10^{-5^{*}}$ \\
\hline Butyrate & $2.0 \times 10^{-6}$ & $6.0 \times 10^{-6^{*}}$ \\
\hline
\end{tabular}

*: the reliability of differences in the parameters of $\mathrm{P}<0.05$ in relation to the group $\mathrm{S}$. typhimurium + Vancomycin.

and S.enteritidis, the main agents of gastroenteritis development, against the background of the dysbiotic changes in the intestinal microflora, can enhance the formation of NETs due to the action of superoxidedismutase [60-62].

\section{Conclusions}

1. The administration of vancomycin caused an increase in the number of Sytox ${ }^{+}$cells in scrapings of the ileal mucosa and in the blood of rats. In pre-treatment of animals with vancomycin and infection of S.enteritidis and S.typhimurium, there was also an increase in the content of Sytox cells in scrapings from the ileal mucosa and in the blood, and the number of NETs decreased. The administration of B.fragilis to experimental animals receiving S. enteritidis and S. typhimurium against the background of vancomycin pretreatment leads to a decrease in the number of Sytox ${ }^{+}$cells in scrapings from the ileal mucosa and in the blood, but induces the generation of NETs, which increases significantly the effectiveness of phagocytosis in the development of gastroenteritis salmonella etiology.

2. The conducted chromatography-mass spectrometric analysis showed that the administration of $B$. fragilis to animals pretreated with vancomycin followed by infection with S. typhimurium causes an increase in the level of SCFA concentration, which contributes to a decrease 
in salmonella-induced inflammation and restoration of intestinal epithelial integrity.

Prospects for further research are the study of the transcriptome of the immune response genes in the intestinal lymphoid tissue of rats with salmonella-induced inflammation.

Conflicts of Interest: authors have no conflict of interest to declare. Конфлікт інтересів: віАсутній.

Information about authors:

Bukina Yu. V., Assistant of the Department of Microbiology, Virology and Immunology, Zaporizhzhia State Medical University, Ukraine.

Varynskyi B. O., PhD, Associate Professor of the Department of Physical and Colloidal Chemistry, Zaporizhzhia State Medical University, Ukraine.

Voitovich A. V., PhD, Senior Lecturer of the Department of Microbiology, Virology and Immunology, Zaporizhzhia State Medical University, Ukraine.

Koval G. D., MD, PhD, DSc, Associate Professor of the Department of Clinical Immunology, Allergology and Endocrinology, HSEE of Ukraine "Bukovinian State Medical University", Chernivtsi Kaplaushenko A. G., Dr.hab., Associate Professor, Head of the Department of Physical and Colloidal Chemistry, Zaporizhzhia State Medical University, Ukraine.

Kamyshnyi O. M., MD, PhD, DSc, Professor, Head

of the Department of Microbiology, Virology and Immunology, Zaporizhzhia State Medical University, Ukraine.

\section{Відомості про авторів:}

Букіна Ю. В., асистент каф. мікробіології, вірусології та імуномогії, Запорізький державний медичний університет, Україна.

Варинський Б. О., канА. фарм. наук, Аоцент каф. фізколоїдної хімії, Запорізький державний медичний університет, Україна. Войтович О. В., канА. біол. наук, старший викладач каф. мікробіології, вірусології та імунології, Запорізький Аержавний медичний університет, Україна.

Коваль Г. А., А-р меА. наук, Аоцент, професор каф. клінічної імунології, алергології та ендокринології, ВАНЗ України “Буковинський державний медичний університет", м. Чернівці, Україна.

Каплаушенко А. Г., А-р фарм. наук, Аоцент, зав. каф. фізколоїдної хімії, Запорізький державний медичний університет, Україна. Камишний О. М., А-р меА. наук, професор, зав. каф. мікробіології, вірусології та імунології, Запорізький Аержавний медичний університет, Україна.

\section{Сведения об авторах:}

Букина Ю. В., ассистент каф. микробиологии, вирусологии и иммунологии, Запорожский государственный медицинский университет, Украина.

Варинский Б. А., к-т фарм. наук, Аоцент каф. физкомлоидной химии, Запорожский государственный меАицинский университет, Украина.

Войтович А. В., канА. биологических наук, старший преподаватель каф. микробиологии, вирусологии и иммунологии, Запорожский государственный меАицинский университет, Украина.

Коваль Г. А., А-р меА. наук, Аоцент, профессор каф. киинической иммунологии, амергологии и энАокринологии, ВГУЗ Украины "Буковинский государственный медицинский университет", г. Черновцы, Украина.

Каплаушенко А. Г., А-р фарм. наук, Аоцент, зав. каф. физкомоиАной химии, Запорожский государственный медицинский университет, Украина.

Камышный А. М., А-р меА. наук, профессор, зав. каф. микробиологии, вирусологии и иммунологии, Запорожский государственный меАицинский университет, Украина.

Надійшла Ао редакції / Received: 30.01.2018

Після Аоопрацювання / Revised: 23.02.2018

Прийнято Ао Аруку / Accepted: 02.03.2018
References

[1] Furusawa, Y., Obata, Y., Fukuda, S., Endo, T. A., Nakato, G., Takahashi, D., et al. (2013) Commensal microbe-derived butyrate induces the differentiation of colonic regulatory T cells. Nature, 504, 446-450. doi: 10.1038/nature12721.

[2] Smith, P. M., Howitt, M. R., Panikov, N., Michaud, M., Gallini, C. A. Bohlooly, Y. M., et al. (2013) The microbial metabolites, short-chain fatty acids, regulate colonic Treg cell homeostasis. Science, 341, 569-573. doi: 10.1126/science.1241165

[3] Masui, R., Sasaki, M., Funaki, Y., Ogasawara, N., Mizuno, M., lida, A. et al. (2013) G protein-coupled receptor 43 moderates gut inflammation through cytokine regulation from mononuclear cells. Inflammatory bowel diseases, 19, 2848-2856. doi: 10.1097/01.MIB.0000435444.

[4] Pluznick, J. A. (2014) Novel SCFA receptor, the microbiota, and blood pressure regulation. Gut Microbes, 5, 202-207. doi: 10.4161/ gmic.27492.

[5] Bukina, Yu. V., Kamyshnyi, A. M., Polishchuk, N. N., \& Topol, I. A. (2017) Sal'monella-inducirovannye izmeneniya kishechnoj mikrobioty transkriptoma genov immunnogo otveta na fone vvedeniya vankomicina Bacteroides fragilis [Salmonella-induced changes in the gut microbiota and immune response genes transcriptome during administration of vancomycin and Bacteroides fragilis]. Pathologia, 14, 1(39), 12-19. [in Russian]. doi: https://doi.org/10.14739/2310-1237.2017.1.97504.

[6] Pieterse, E., Rother, N., Yanginlar, C., Hilbrands, L. B., \& Vlag van der, J. (2016) Neutrophils Discriminate between Lipopolysaccharides of Different Bacterial Sources and Selectively Release Neutrophil Extracellula Traps. Frontiers in Immunology, 7, 484. doi: 10.3389/fimmu.2016.00484.

[7] Dabrowska, D., Jabłońska, E., Garley, M., Ratajczak-Wrona, W., \& Iwaniuk, A. (2016) New Aspects of the Biology of Neutrophil Extracellular Traps. Scandinavian Journal of Immunology, 84, 317-322. doi: $10.1111 / \mathrm{sji} .12494$

[8] Remijsen, Q., Kuijpers, T., Wirawan, E., Lippens, S., Vandenabeele, P. \& Vanden Berghe, T. (2011) Dying for a cause: NETosis, mechanisms behind an antimicrobial cell death modality. Cell Death \& Differentiation 18(4), 581-588. doi: 10.1038/cdd.2011.1.

[9] Kaplan, M. J., \& Radic, M. (2012) Neutrophil extracellular traps: Double-edged swords of innate immunity. The Journal of Immunology, 189(6), 2689-2695. doi: 10.4049/jimmunol.1201719.

[10] Von Köckritz-Blickwede, M., \& Nizet, V. (2009) Innate immunity turned inside-out: antimicrobial defense by phagocyte extracellular traps. Journal of Molecular Medicine, 87(8), 775-783. doi: 10.1007/ s00109-009-0481-0.

[11] Urban, C. F., Reichard, U., Brinkmann, V., Zychlinsky, A. (2006) Neutrophil extracellular traps capture and kill Candida albicans yeast and hyphal forms. Cell Microbiology, 8(4), 668-676. doi: 10.1111/j.1462 5822.2005.00659.x

[12] Urban, C. F., Ermert, D., Schmid, M., Abu-Abed, U., Goosmann, C. Nacken, W., et al. (2009) Neutrophil extracellular traps contain calprotectin, a cytosolic protein complex involved in host defense against Candida albicans. PLoS Pathology, 5(10), e1000639. doi: 10.1371/ journal.ppat.1000639.

[13] Arazna, M., Pruchniak, M. P., \& Demkow, U. (2013) Neutrophil extracellular traps in bacterial infections: Strategies for escaping from killing. Respiratory Physiology \& Neurobiology, 187(1), 74-77. doi: 10.1016/j. resp.2013.03.002.

[14] Yipp, B. G., Petri, B., Salina, D., Jenne, C. N., Scott, B. N., Zbytnuik, L. D., et al. (2012) Infection-induced NETosis is a dynamic process involving neutrophil multitasking in vivo. Natural Medicine, 18(9), 1386-1393. doi: 10.1038/nm.2847.

[15] Dworski, R., Simon, H-U., Hoskins, A., \& Yousefi, S. (2011) Eosinophil and neutrophil extracellular DNA traps in human allergic asthmatic airways. Journal of Allergy and Clinical Immunology, 127(5), 1260-1266. doi: 10.1016/j.jaci.2010.12.1103

[16] Konstantinidis, T., Kambas, K., Mitsios, A., Panopoulou, M., Tsironidou, V., Dellaporta, E., et al. (2015) Immunomodulatory Role of Clarithromycin in Acinetobacter baumannii Infection via Formation of Neutrophil Extracellular Traps. Antimicrobial Agents and Chemotherapy, 60(2), 1040-1048. doi: 10.1128/AAC.02063-15.

[17] Jagtap, A. G., Shirke, S. S., \& Phadke, A. S. (2004) Effect of polyherbal formulation on experimental models of inflammatory bowel diseases. Journal of Ethnopharmacology, 90(2-3), 195-204. doi: 10.1016/j. jep.2003.09.042.

[18] Loginov, V. A., Ardatskaya, M. D., \& Minushkin, O. N. (2014) Syndrome of excessive bacterial growth in patients with a decreased acid-producing function of the stomach. Experimental and clinical gastroenterology, 12, 30-36.

[19] Marcos, V., Zhou, Z., Yildirim, A. O., Bohla, A., Hector, A., Vitkov L, et al. (2010) CXCR2 mediates NADPH oxidase-independent neutrophil extracellular trap formation in cystic fibrosis airway inflammation. Natural Medicine, 16, 1018-1023. doi: 10.1038/nm.2209.

[20] Dubois, A. V., Gauthier, A., Bréa, D. Varaigne, F., Diot, P., Gauthier, F. \& Attucci, S. (2012) Influence of DNA on the activities and inhibition of neutrophil serine proteases in cystic fibrosis sputum. American Journal of Respiratory Cell and Molecular Biology, 47, 80-86. doi: 10.1165 rcmb.2011-03800C.

[21] Delgado-Rizo, V., Martínez-Guzmán, M. A., Iñiguez-Gutierrez, L., 
García-Orozco, A., Alvarado-Navarro, A., \& Fafutis-Morris, M. (2017) Neutrophil Extracellular Traps and Its Implications in Inflammation: An Overview. Frontiers in Immunology, 8, 81. doi: 10.3389/fimmu. 2017.00081.

[22] Pilsczek, F. H., Salina, D., Poon, K. K., Fahey, C., Yipp, B. G., Sibley, C. D., et al. (2015) A novel mechanism of rapid nuclear neutrophil extracellular trap formation in response to Staphylococcus aureus. Journal of Immunology, 185(12), 7413-7425. doi: 10.4049/jimmunol.1000675.

[23] Al-Khafaji, A. B., Tohme, S., Yazdani, H. O., Miller, D., Huang, H., \& Tsung, A. (2016) Superoxide induces neutrophil extracellular trap formation in a TLR-4 and NOX-dependent mechanism. Molecular Medicine, 22, 621-631. doi: 10.2119/molmed.2016.00054.

[24] Lewis, H. D., Liddle, J., Coote, J. E., Atkinson, S. J., Barker, M. D., Bax, B. D., et al. (2015) Inhibition of PAD4 activity is sufficient to disrupt mouse and human NET formation. Nature Chemical Biology, 11(3), 189-191. doi: 10.1038/nchembio.1735.

[25] Li, P., Li, M., Lindberg, M. R., Kennett, M. J., Xiong, N., \& Wang, Y. (2010) PAD4 is essential for antibacterial innate immunity mediated by neutrophil extracellular traps. The Journal of Experimental Medicine, 207, 1853-1862. doi: 10.1084/jem.20100239.

[26] Papayannopoulos, V., Metzler, K. D., Hakkim, A., \& Zychlinsky, A. (2010) Neutrophil elastase and myeloperoxidase regulate the formation of neutrophil extracellular traps. The Journal of Cell Biology, 191(3), 677-691. doi: 10.1083/jcb.201006052.

[27] Neeli, I., Khan, S. N., \& Radic, M. (2008) Histone deimination as a response to inflammatory stimuli in eutrophils. Journal of Immunology, 180, 1895-1902. doi: https://doi.org/10.4049/jimmunol. 180.3.1895

[28] Branitzki-Heinemann, K., Möllerherm, H., Völlger, L., Husein, D. M., Buhr, de N., Blodkamp, S., et al. (2016) Formation of neutrophil extracellular traps under low oxygen level. Frontiers in Immunology, 7, 518. doi: 10.3389/fimmu.2016.00518.

[29] Douda, D. N., Khan, M. A., Grasemann, H., \& Palaniyar, N. (2015) SK3 channel and mitochondrial ROS mediate NADPH oxidase-independent NETosis induced by calcium influx. Proceedings of the National Academy of Sciences, 112(9), 2817-2822. doi: 10.1073/ pnas. 1414055112

[30] Yipp, B. G., \& Kubes, P. (2013) NETosis: how vital is it? Blood, 122(16), 2784-2794. doi: 10.1182/blood-2013-04-457671.

[31] Byrd, A. S., O'Brien, X. M., Johnson, C. M., Lavigne, L. M., \& Reichner, J. S. (2013) An extracellular matrix-based mechanism of rapid neutrophil extracellular trap formation in response to Candida albicans. Journal of Immunology, 190(8), 4136-4148. doi: 10.4049/ jimmunol.1202671.

[32] Clark, S. R., Ma, A. C., Tavener, S. A., McDonald, B., Goodarzi, Z., Kelly, M. M., et al. (2007) TLR4 activates neutrophil extracellular traps to ensnare bacteria in septic blood. Natura Medicine, 13(4), 463-469. doi: $10.1038 / \mathrm{nm} 1565$

[33] Yipp, B. G., Petri, B., Salina, D., Jenne, C. N., Scott, B. N. V., Zbytnuik, L. D., et al. (2012) Dynamic NETosis is carried out by live neutrophils in human and mouse bacterial abscesses and during severe gram-positive infection. Natura Medicina, 18(9), 1386-1393. doi: $10.1038 / \mathrm{nm} .2847$.

[34] Carestia, A., Kaufman, T., Rivadeneyra, L., Landoni, V. I., Pozner, R. G., Negrotto, S., et al. (2016) Mediators and molecular pathways involved in the regulation of neutrophil extracellular trap formation mediated by activated platelets. Journal of Leukocyte Biology, 99(1), 153-162. doi: 10.1189/jlb.3A0415-161R

[35] Yousefi, S., Mihalache, C., Kozlowski, E., Schmid, I., \& Simon, H. U. (2009) Viable neutrophils release mitochondrial DNA to form neutrophil extracellular traps. Cell Death \& Differentiation, 16, 1438-1444. doi: $10.1038 /$ cdd.2009.96.

[36] Sørensen, O. E., \& Borregaard, N. (2016) Neutrophil extracellular traps - the dark side of neutrophils. Journal of Clinical Investigation, 126(5), 1612-1620. doi: 10.1172/JCl84538.

[37] Masuda, S., Nakazawa, D., Shida, H., Miyoshi, A., Kusunoki, Y., Tomaru, U., \& Ishizu, A. (2016) NETosis markers: Quest for specific, objective, and quantitative markers. Clinica Chimica Acta, 459, 89-93. doi: 10.1016/j.cca.2016.05.029.

[38] de Buhr, N., \& von Köckritz-Blickwede, M. (2016) How Neutrophil Extracellular Traps Become Visible. Journal of Immunology Research, 3, 1-13. doi: 10.1155/2016/4604713.

[39] Corrêa-Oliveira, R., Fachi, J. L., Vieira, A., Sato, F. T., \& Vinolo, M. A. (2016) Regulation of immune cell function by short-chain fatty acids. Clinical \& Translational Immunology, 5(4), e73. doi: 10.1038/ cti.2016.17.

[40] Rodrigues, H. G., Takeo Sato, F., Curi, R., \& Vinolo, M. A. (2016) Fatty acids as modulators of neutrophil recruitment, function and survival. European Journal of Pharmacology, 785, 50-58. doi: 10.1016/j.ejphar.2015.03.098

[41] Vinolo, M. A Rodrigues, H. G. Hatanaka, E Sato, F. T. Sampaio, S. C., \& Curi, R. (2011) Suppressive effect of short-chain fatty acids on production of proinflammatory mediators by neutrophils. The Journal of Nutritional Biochemistry, 22(9), 849-855. doi: 10.1016/j. jnutbio.2010.07.009.

[42] Vinolo, M. A., Ferguson, G. J., Kulkarni, S., Damoulakis, G., Ander- son, K., Bohlooly, Y. M., et al. (2011) SCFAs induce mouse neutrophil chemotaxis through the GPR43 receptor. PLOS ONE, 6(6), e21205. doi: $10.1371 /$ journal.pone.0021205

[43] Tedelind, S., Westberg, F., Kjerrulf, M., \& Vidal, A. (2007) Anti-inflammatory properties of the short-chain fatty acids acetate and propionate: a study with relevance to inflammatory bowel disease. World Journal of Gastroenterology, 13(20), 2826-2832. doi: 10.3748/ wjg.v13.i20.2826.

[44] Sina, C., Gavrilova, O., Förster, M., Till, A., Derer, S., Hildebrand, F., et al. (2009) $\mathrm{G}$ protein-coupled receptor 43 is essential for neutrophil recruitment during intestinal inflammation. Journal of Immunology, 183(11), 7514-7522. doi: 10.4049/jimmunol.0900063.

[45] Le Poul, E., Loison, C., Struyf, S., Springael, J. Y., Lannoy, V., Decobecq, M. E., et al. (2003) Functional characterization of human receptors for short chain fatty acids and their role in polymorphonuclear cell activation. The Journal of Biological Chemistry, 278(28), 25481-25489. doi: 10.1074/jbc.M301403200.

[46] Maslowski, K. M., Vieira, A. T., Ng, A., Kranich, J., Sierro, F., Schilter, H. C., et al. (2009) Regulation of inflammatory responses by gut microbiota and chemoattractant receptor GPR43. Nature, 461(7268) 1282-1286. doi: 10.1038/nature08530.

[47] Furusawa, Y., Obata, Y., Fukuda, S., Endo, T. A., Nakato, G., Takahashi, D., et al. (2013) Commensal microbe-derived butyrate induces the differentiation of colonic regulatory T cells. Nature, 504(7480), 446-50. doi: 10.1038/nature12721

[48] Smith, P. M., Howitt, M. R., Panikov, N., Michaud, M., Gallini, C. A. Bohlooly, Y. M., et al. (2013) The microbial metabolites, short-chain fatty acids, regulate colonic Treg cell homeostasis. Science, 341(6145), 569-73. doi: 10.1126/science.1241165.

[49] Vinolo, M. A., Rodrigues, H. G., Nachbar, R. T., Curi, R. (2011) Regulation of inflammation by short chain fatty acids. Nutrients, 3(10), 858-876. doi: 10.3390/nu3100858.

[50] Vinícius, A. O., Câmara, N. O. S., \& Moraes-Vieira, M. P. (2015) Adipokines as Drug Targets in Diabetes and Underlying Disturbances. Journal of Diabetes Research, 2015, 11. doi: http://dx.doi. org/10.1155/2015/681612

[51] Mishiro, T., Kusunoki, R., Otani, A., Ansary, M. M., Tongu, M., Harashima, N., et al. (2013) Butyric acid attenuates intestinal inflammation in murine DSS-induced colitis model via milk fat globule-EGF factor 8. Laboratory Investigation, 93(7), 834-843. doi: 10.1038/labinvest.2013.70.

[52] Kim, M., Qie, Y., Park, J., \& Kim, C. H. (2016) Gut Microbial Metabolites Fuel Host Antibody Responses. Cell Host \& Microbe, 20(2), 202-14. doi: 10.1016/j.chom.2016.07.001.

[53] Mills, S. W., Montgomery, S. H., \& Morck, D. W. (2006) Evaluation of the effects of short-chain fatty acids and extracellular $\mathrm{pH}$ on bovine neutrophil function in vitro. American Journal of Veterinary Research, 67(11), 1901-1907. doi: 10.2460/ajvr.67.11.1901.

[54] Usami, M., Kishimoto, K., Ohata, A., Miyoshi, M., Aoyama, M., Fueda, Y., \& Kotani, J. (2008) Butyrate and trichostatin A attenuate nuclear factor kappaB activation and tumor necrosis factor alpha secretion and increase prostaglandin E2 secretion in human peripheral blood mononuclear cells. Nutrition Research, 28(5), 321-8. doi: 10.1016/j. nutres.2008.02.012

[55] Maslowski, K. M., Vieira, A. T., Ng, A., Kranich, J., Sierro, F., Schilter, H. C., et al. (2009) Regulation of inflammatory responses by gut microbiota and chemoattractant receptor GPR43. Nature, 461(7268), 1282-1286. doi: 10.1038/nature08530.

[56] Aoyama, M., Kotani, J., \& Usami, M. (2010) Butyrate and propionate induced activated or non-activated neutrophil apoptosis via HDAC inhibitor activity but without activating GPR-41/GPR-43 pathways. Nutrition, 26(6), 653-61. doi: 10.1016/j.nut.2009.07.006.

[57] Papayannopoulos, V. (2018) Neutrophil extracellular traps in immunity and disease. Nature Reviews Immunology, 18(2), 134-147. doi: 10.1038/nri.2017.105

[58] Grinberg, N., Elazar, S., Rosenshine, I., Shpigel, N. Y. (2008) Beta-hydroxybutyrate abrogates formation of bovine neutrophil extracellular traps and bactericidal activity against mammary pathogenic Escherichia coli. Infections Immunology, 76(6), 2802-2807. doi: 10.1128/ IAI.00051-08.

[59] Corrêa, R. O., Vieira, A., Sernaglia, E. M., Lancellotti, M., Vieira, A. T., Avila-Campos, M. J., et al. (2017) Bacterial short-chain fatty acid metabolites modulate the inflammatory response against infectious bacteria. Cellular Microbiology 19(7) e12720 doi: 10.1111/cmi.12720.

[60] Brinkmann, V., Reichard, U., Goosmann, C., Fauler, B., Uhlemann, Y., Weiss, D. S., et al. (2004) Neutrophil extracellular traps kill bacteria. Science, 303(5663), 1532-1535. doi: 10.1126/science.1092385.

[61] Ibarra, J. A., \& Steele-Mortimer, O. (2009) Salmonella - the ultimate insider Salmonella virulence factors that modulate intracellular survival. Cellular Microbiology, 11(11), 1579-1586. doi: 10.1111/j.14625822.2009.01368 x

[62] Pacello, F., Ceci, P., Ammendola, S., Pasquali, P., Chiancone, E., \& Battistoni, A. (2008) Periplasmic Cu, Zn superoxide dismutase and cytoplasmic Dps concur in protecting Salmonella enterica serovar Typhimurium from extracellular reactive oxygen species. Biochimica et Biophysica Acta, 1780(2), 226-232. doi: 10.1016/j.bbagen.2007.12.001. 